УДК 373.542:811.161.2

Кучерук Оксана Анатоліївна

доктор педагогічних наук, доцент, професор кафедри дидактичної лінгвістики та літературознавства Житомирський державний університет ім. Івана Франка, м. Житомир, Україна

okucheruk1@rambler.ru

\title{
ОСНОВНІ НАПРЯМИ РОЗВИТКУ ЕЛЕКТРОННОЇ ЛІНГВОДИДАКТИКИ
}

\begin{abstract}
Анотація. У статті розглядається проблема електронної лінгводидактики. Обгрунтовано актуальність створення й використання нових програмних засобів інформаційнокомунікаційних технологій 3 метою підвищення якості україномовної освіти. Шляхом аналізу і синтезу науково-методичних ідей визначено основні напрями розвитку вітчизняної електронної лінгводидактики, що пов'язані з розробленням електронних лексикографічних праць навчального призначення, підручників і навчальних посібників, електронних версій навчально-методичних комплексів, навчально-методичних портфелів в електронному форматі, уроків з використанням ІКТ, зі створенням електронних навчальних курсів, блогів і сайтів навчально-методичного спрямування, з проведенням наукових досліджень у сфері електронного навчання української мови. 3'ясовано вітчизняний досвід розроблення й упровадження програмного інструментарію в процес комп'ютерного навчання української мови.
\end{abstract}

Ключові слова: електронна лінгводидактика; електронні засоби навчання; електронний навчальний курс; інформаційно-комунікаційні технології.

\section{1. ВСТУП}

Постановка проблеми. Сучасні тенденції розвитку інформаційнокомунікаційних технологій в освіті загалом і в україномовній освіті зокрема формують об'єктивні умови для переходу теорії і практики навчання української мови на новий технологічний рівень, пов'язаний 3 електронною лінгводидактикою, яка, оперуючи досягненнями традиційної лінгводидактики, виконує специфічні завдання обгрунтування принципів електронного навчання мови, створення й ефективного впровадження комп'ютерно орієнтованих засобів навчання та IКТ у систему мовної освіти. Тому не втрачає актуальності, педагогічної цінності розроблення, використання й популяризація нових електронних програмних засобів навчального призначення 3 метою підвищення якості україномовної освіти.

Аналіз останніх досліджень і публікацій. Окремі аспекти порушеної проблеми відображено в наукових працях В. Бадер, Ж. Горіної, Г. Дідук-Ступ'як, С. Караман, К. Климової， Т. Котик， А. Надолинської， А. Нікітіної， С. Омельчука， Л. Струганець, Г. Шелехової та ін. У роботах цих авторів висвітлено деякі теоретико-практичні питання створення й використання програмних засобів інформаційно-комунікаційних технологій (IКТ) у системі україномовної освіти. Зокрема, Л. Мацько, Т. Кудіна розробили інтернет-адаптоване навчально-методичне забезпечення навчального курсу української мови як іноземної для слухачів підготовчого відділення вищого навчального закладу - ідеться про створення мережевого навчально-методичного комплексу для позааудиторного навчання, який складається з колекції «відібраних» україномовних фільмів, мультимедійного банку інтерактивних діалогів, тлумачного аудіословника, що уможливлює збільшення часу перебування іноземця в україномовному середовищі [5]. Загалом аналіз праць дидактиків-філологів свідчить, що у фахових публікаціях розкрито питання становлення електронної лінгводидактики (е-лінгводидактики) як інноваційного науково-методичного напряму, лінгводидактичні можливості комп’ютерної лексикографії, особливості комп'ютерних тестів у системі 
контролю навчальних досягнень носіїв мови, визначено підходи до створення електронної книги для навчання української мови, методично обгрунтовано систему роботи з використання ІКТ у процесі мовленнєвого розвитку дошкільників та ін. Незважаючи на інтерес учених до питань використання в системі україномовної освіти електронних ресурсів, теорія проблеми розроблена недостатньо, а в практиці навчання української мови програмні засоби ІКТ використовуються неповною мірою.

Мета статті - розкрити основні напрями розвитку вітчизняної електронної лінгводидактики, які дають змогу сформувати закономірності комп'ютерного навчання української мови. Завдання: визначити шляхи розвитку е-лінгводидактики, з'ясувати вітчизняний досвід створення й упровадження електронних програмних засобів у процес комп'ютерного навчання української мови, окреслити лінгвометодичні можливості використання їх у системі україномовної освіти.

\section{2. МЕТОДИ ДОСЛІДЖЕННЯ}

Під час дослідження використовувалися такі методи наукового пізнання: аналіз теоретичних джерел 3 проблем інноваційних методик організації навчання української мови; вивчення й узагальнення передового досвіду створення комп'ютерно орієнтованих засобів навчання, електронних програмних продуктів навчальнометодичного спрямування та застосування їх у системі україномовної освіти; аналіз, порівняння, інтерпретація результатів дослідної роботи.

\section{3. РЕЗУЛЬТАТИ ДОСЛІДЖЕННЯ}

Реалії сьогодення такі, що галузь україномовної освіти недостатньо забезпечена електронними програмними продуктами навчального призначення, більшість досвідчених філологів-методистів, педагогів-практиків не готові повною мірою брати участь у творчій співпраці зі створення програмних засобів для комп'ютерного навчання української мови, не всі вчителі володіють методикою використання мультимедійних засобів (комп'ютерної графіки, гіпертексту, звукових файлів, анімації, відеоресурсу) у навчальному процесі формування зростаючої мовної особистості, не завжди готові до забезпечення необхідних психолого-педагогічних і методичних умов для комп'ютерного навчання, відчувають суттєві труднощі в роботі з комп'ютером та ІКТ. Водночас творчі педагоги напрацювали певний досвід теорії і практики комп'ютерного навчання української мови. Завдяки їм елінгводидактика змінює усталені уявлення про мовну освіту.

У розвитку вітчизняної електронної лінгводидактики можна виділити кілька основних актуальних і водночас перспективних напрямів: 1) розроблення електронних лексикографічних продуктів навчального спрямування; 2) розроблення електронних навчальних підручників, посібників, а також методичних рекомендацій до такого типу електронних педагогічних програмних засобів; 3) теоретичне обгрунтування i створення предметно-методичних портфелів в електронному форматі, уроків 3 комп'ютерною підтримкою; 4) розроблення електронних навчальних курсів; 5) створення блогів, сайтів навчально-методичного спрямування 3 використанням комп'ютерної техніки й ресурсів мережі Інтернет; 6) здійснення теоретикоекспериментальних досліджень актуальних питань упровадження засобів IКТ в практиці мовної освіти. Розглянемо ці напрями як шляхи розвитку вітчизняної електронної лінгводидактики детальніше.

Побудова електронних лексикографічних продуктів навчального призначення й теоретичне обгрунтування їх доцільності, освітньої вартості - новий напрям у 
лінгводидактиці. Електронний навчальний словник — це електронна база словникових статей, створена 3 навчальною метою. Концепція розроблення електронних навчальних лексикографічних праць має враховувати, що електронні словники можуть бути постійними (уміщені на компактних магнітних, лазерних дисках чи інших електронних носіях інформації, які мають значний обсяг пам'яті й підключаються до комп'ютера) і змінними (представлені в глобальній мережі Інтернет, передбачають періодичне внесення певної лексики в такі словники, редагування помилок, усунення неточностей). Освітня цінність електронних навчальних словників залежатиме від того, чи буде в електронному корпусі словникової статті подаватися транскрипція слова, озвучення правильної вимови заголовного слова статті, інформація про синоніми, антоніми, відмінювання заданого слова, приклади його слововживання в контексті, чи міститимуть такі лексикографічні ресурси не лише текстовий, а й гіпертекстовий матеріал 3 малюнками, відеофрагментами, аудіосупроводом, чи забезпечуватимуть одночасний швидкий пошук слів як за назвою словникових статей, так і в усіх текстах конкретного електронного словника. Прикладом електронної лексикографічної праці навчального спрямування $\epsilon$ мультимедійний лінгвокультурологічний словник «Концепти української культури», розроблений насамперед для викладачів і студентів-

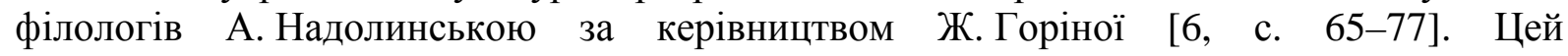
лексикографічний продукт створено за допомогою програмного забезпечення «Help \& Manual. Professional Edition» обсягом у 200 MB й записано на окремому CD диску. 3 погляду електронної лінгводидактики особливістю зазначеного навчального словника є те, що він орієнтується на користувача ПК - для кожного концепту відведено динамічну сторінку в електронному форматі з текстовим описом заголовного слова чи словосполучення, ілюстраціями, музичним супроводом; відбір лексичних одиниць для мовної репрезентації концептів української культури здійснено на базі художніх, публіцистичних текстів, джерел усної народної творчості; у словникових статтях до слова-концепта використано яскравий ілюстративний матеріал завдяки мультимедійному складнику (комп’ютерна графіка, анімація, відео- і звуковий супровід гіпертексту); словникові статті кожного тематичного розділу («Флора», «Фауна», «Побут», «Духовно-культурні концепти») одночасно виконують довідкову й навчальну функції; відповідно до принципу методичної доцільності в мультимедійному словнику вміщено слова-концепти, які стимулюють інтерес користувачів цього словника до української мови як навчальної дисципліни тощо.

Один із шляхів розвитку електронної лінгводидактики, який веде до модернізації форми і змісту навчальної та методичної літератури, становить застосування засобів IКТ до розроблення електронних навчальних підручників, посібників, методичних рекомендацій до них в електронному форматі. На відміну від традиційних, паперових, електронні навчальні чи методичні книги містять великий обсяг інформації й водночас легкі в користуванні. Особливістю розроблення запитаних електронних навчальних книг $€$ достатня й необхідна повнота тематичної інформації, логічність і послідовність викладу навчального матеріалу, належне й зручне структурування гіпертексту в електронній формі, якісний рівень наочності, методичного інструментарію, естетичне оформлення 3 використанням технологій мультимедіа, спрямування на використання різних типів електронної комунікації. Завдяки таким особливостям відповідна навчальна книга як електронний педагогічний програмний засіб комплексно впливає на різні канали сприйняття того, хто нею користується. У такому підручнику основний матеріал модуля, тобто блоку, розділу, пов'язується за допомогою гіперпосилань - виділених слів чи фраз, на яких потрібно клацнути мишкою, щоб швидко перейти до потрібного матеріалу. Навігаційна система уможливлює доступ користувачам електронної книги до словників, довідкових матеріалів. Зміст у навчальному електронному виданні структурується за 
принципом програмованого навчання, відповідно тематичний матеріал розміщується порціями: презентація основних відомостей (у вигляді тексту, схем, таблиць, малюнків, аудіо-відеоматеріалів та ін.), навчальні завдання різного характеру складності, підказки, контрольні запитання, проміжні тематичні тести, правильне виконання яких уможливлює доступ до наступної порції матеріалу, як правило, подальшого модуля. Як приклад можна назвати електронний педагогічний програмний засіб «Українська мова. Готуйся серйоЗНО», розроблений С. Омельчуком з метою активізації навчальної діяльності учнів шляхом виконання тестових завдань різних форм і рівнів складності [7]. У змісті i структурі цього електронного практикуму охоплено п'ять розділів шкільного курсу української мови. В основу розроблення тематичних тестів і завдань контрольного тесту покладено такі принципи: послідовності, покроковості, доступності, інтегративності, предметно-практичного спрямування, зв'язку теорії з практикою, різнорівневої складності. Для роботи з електронним практикумом учень має зареєструватися у відповідному вікні програми, потім - вибрати розділ для самостійної роботи, затим - варіант тесту. Для виконання тематичних тестів передбачено п’ять спроб заміни учнем вибраних відповідей. У вікні «Результат тестування» комп'ютерної програми можна ознайомитися з кількістю правильно виконаних завдань i набраними балами. Серед позитивів програми електронного практикуму є розділ «Робота над помилками» - самостійно виправити допущені помилки учень може, опрацювавши теоретичні матеріали, доступно подані під неправильно виконаним завданням. У контексті сказаного потрібно зазначити, що 3 активним розвитком окресленого напряму е-лінгводидактики постає питання про доцільність тих електронних навчальних підручників і посібників з української мови, автори яких буквально переносять друковане паперове видання в електронний формат, створюючи цифрову копію паперових видань відповідних книг - такі електронні книги мають паперовий попередник і повністю збігаються з ним.

В освітній сфері IКТ упроваджуються за такими основними напрямами діяльності: у підготовці педагога до навчальних занять, під час навчання як співдіяльності в аудиторії, у процесі самостійної індивідуальної роботи учнів, зокрема й в умовах дистанційного навчання. У підготовчій роботі до організації й проведення навчальних занять із застосуванням IКТ педагог може скористатися пошуковими системами Інтернету, зайти на сайти, які містять навчальні матеріали, пояснення до текстів, дидактичні ігри, кросворди, відеоролики, а також створити власну освітню веб-сторінку тощо. Окремої уваги потребує створення вчителем в електронному форматі предметно-методичного портфелю (інші назви - досьє успіхів, папка успіху, папка фахівця, збірник власних досягнень, портфоліо), зокрема його різновиду веб-портфоліо, який є глобально доступним для користувачів Інтернету. Загалом предметно-методичний портфель учителя мови - це спосіб нагромадження й зберігання лінгвометодичних матеріалів, які свідчать про рівень професійної компетентності педагога. У лінгвометодичному портфелі вчителя містяться папки 3 освітніми документами, власне мовними, предметно-демонстраційними, навчально-розвивальними, соціокультурними, дослідницькими, звітними матеріалами. Переваги електронних локального і глобального лінгвометодичних портфелів у тому, що значна за обсягом інформація вміщується на компактних електронних носіях пам'яті й може бути гарно представлена за допомогою ресурсів мультимедіа. У процесі підготовки вчителя до проведення сучасного уроку, до організації навчання 3 використанням комп'ютерних програм і ресурсів мережі Інтернет практичне значення має благодійна освітня програма корпорації Intel «Навчання для майбутнього» [1]. Ця програма пропонує сучасний досвід ефективного використання IКТ в освіті, який педагог може адаптувати до специфіки навчального предмета за умови наявності необхідних професійно-педагогічних умінь, зокрема вмінь працювати 3 комп'ютером і 3 освітніми ресурсами Інтернету. Користуючись цією освітньою програмою, учитель може розробити навчальний проект і 
відповідні навчальні, методичні матеріали за допомогою комп’ютерних програм Microsoft Office (PowerPoint, Publisher, Word), а також залучити учнів до самостійної дослідницької діяльності, використовуючи комп'ютер для спілкування в Інтернеті, здійснення пошуку тематичної інформації в глобальній мережі, створення публікацій (інформаційного бюлетеня або буклету), мультимедійних комп'ютерних презентацій, веб-сайтів та ін.

Як було зазначено, серед основних напрямів вітчизняної е-лінгводидактики $\epsilon$ розроблення електронних навчальних курсів, що уможливлює більш ефективне використання навчального часу. Електронний навчальний курс (ЕНК) - це впорядкований комплекс електронних навчально-методичних матеріалів для організації дистанційного індивідуального і групового навчання 3 використанням персонального комп'ютера й інтернет-технологій за умови керівної ролі вчителя. Аналіз педагогічного досвіду електронного навчання свідчить, що однією 3 перспективних безкоштовних систем управління навчанням $€$ Moodle. Ця система містить інструменти для підготовки й проведення занять та для оцінювання навчальних досягнень учнів шляхом застосування сучасних технологій навчання й водночас легка в застосуванні. Електронна форма навчання на основі системи Moodle передбачає підключення і вільний доступ до мережі Інтернет. Загальні положення про побудову електронного навчального курсу на базі платформи дистанційного навчання (ДН) Moodle розроблено в працях Н. Морзе, О. Глазунової, К. Колос та ін. Робота над створенням навчально-предметного курсу відповідного типу багатоаспектний процес, що грунтується на принципах модульності у структуруванні навчально-методичних матеріалів, системності, цілісності представлення інформації з усього навчального курсу, науковості, доступності, відкритості, інтерактивності, технологічності навчання, комп'ютерної візуалізації навчального матеріалу, методичної доцільності змісту навчальних матеріалів і видів навчальної діяльності, можливості вибору індивідуальної траєкторії просування в навчанні, предметно-практичного спрямування тощо. ЕНК у системі мовної освіти має відповідати низці психолого-педагогічних критеріїв, серед них особистісно орієнтоване навчання, поєднання мислення, інтуїції, уявлення, урахування психотипів учнів, їхніх пізнавальних інтересів, персональних когнітивних стилів, а також лінгводидактичних критерів, зокрема комунікативне спрямовання навчального курсу, збагачення лінгвістичного світогляду юних носіїв мови, розширення мовної пам'яті, текстоцентризм у навчанні, поєднання пізнавальної, тренувальної й мовотворчої діяльності та ін. Цікавим є досвід створення ЕНК, напрацьований учителем української мови i літератури Мелітопольської ЗОШ I-III ступенів № 11 Запорізької області Г. Шиліною [8]. Вона на основі використання компонентів системи Moodle розробила і впроваджує ЕНК 3 української мови для 8-го класу за авторською програмою факультативу «Українська мова» (поглиблене вивчення). Зазначений електронний навчальний курс зареєстрований на платформі комунального закладу «Запорізький обласний інститут післядипломної педагогічної освіти» Запорізької обласної ради на сайті «Школа сучасних знань». ЕНК розрахований на 34 години інтенсивного навчання впродовж двох семестрів, заняття проходять дистанційно в мережі Інтернет і становлять одну годину на тиждень, за потреби навчання може відбуватися 3 групою учнів у вигляді індивідуальної і групової форм навчання в комп'ютерному класі, оснащеному спеціальним апаратно-програмним забезпеченням. Мета курсу - розширення й поглиблення програмового матеріалу 3 української мови як навчального предмета шляхом використання персонального комп'ютера й відкритих джерел Інтернету. Тому логічним є впровадження його в традиційну систему україномовної освіти за принципом змішаного навчання. ЕНК становить відкрите навчальне середовище - у процесі навчання він зазнає певних змін, редагування й удосконалюється відповідно до професійного розвитку вчителя. У розробленні курсу на основі вмінь і навичок моделювати інформаційно-навчальне середовище застосовано комп'ютерні методи представлення навчальної інформації в електронному форматі: комп'ютерна візуалізація 
інформаційних схем, гіпертекстова розмітка електронних документів, поєднання аудіо- і відеоматеріалів на електронній сторінці та ін. Навчальні модулі ЕНК містять веб-сторінку з теоретичним матеріалом, комп'ютерну презентацію навчально-тематичних відомостей, практичні завдання з мови різного характеру складності, навчальні й контрольні тести різних видів, запитання для самоконтролю, мовленнєві завдання на основі роботи 3 текстом, на складання творів-роздумів, есе; навчальний курс передбачає перегляд відеороликів, музичних кліпів, роботу з довідковою літературою, створення глосарію та ін. Перевага в навчанні за цим курсом надається самостійній пошуково-дослідницькій i предметнопрактичній діяльності, що забезпечує індивідуалізацію навчання, різні види навчальної активності, значно покращує розуміння навчального матеріалу й інтенсифікує процес україномовної освіти. Електронні навчальні матеріали курсу доставляються суб'єктам навчання за допомогою мережі Інтернет. Після перевірки й оцінювання виконаних учнями завдань учитель виставляє бали в електронний журнал успішності учнів, доступний для перегляду на комп'ютері, - такий журнал уможливлює оперативний доступ до балів, виставлених за весь період його ведення. Отже, цей курс поєднує функції джерела інформації, підручника, довідкового посібника, консультанта, тренажера, засобу контролю. Керівна ж роль у навчанні за цим курсом відводиться вчителю, ефективність роботи вчителя щодо вдалого поєднання комп'ютерного навчання й навчання в глобальній мережі зумовлюється рівнем його комп'ютерної та інформаційної грамотності. Навчальний результат користувачів курсу значною мірою залежить від позитивного психологічного настрою, рівня навчально-предметних досягнень учнів, їхньої комп'ютерної підготовки і компетентності вчителя в галузі е-лінгводидактики. Наведений досвід створення й упровадження ЕНК в шкільну практику навчання української мови може бути застосований під час удосконалення існуючих електронних навчальних курсів і в процесі побудови нових моделей електронного навчання юних носіїв мови. ЕНК, що має теоретичне обгрунтування й перевірений у практиці навчання української мови, забезпечує інноваційний характер навчальної діяльності, створює умови для розширення освітніх можливостей зростаючого носія мови та загалом сприяє модернізації україномовної освіти.

На засадах е-лінгводидактики розроблюються персональні освітні блоги й спеціалізовані сайти. Як приклад можна назвати естетично оформлені блог Г. Корицької «Камертон філолога» [4] й сайт «Камертон філолога: відлуння» [3], що містять документи, інформаційні тексти, презентації підручників, опис досвіду творчих учителів і науковців, узагальнення результатів дослідно-пошукової роботи учнів, відеофрагменти та ін. Ці програмні продукти доступні всім зацікавленим користувачам в індивідуальному режимі й у зручний для них час. Організаційні складники блогу й сайту містять дошки оголошень, системи електронної пошти, форуму, «гостьової книги», відтворення аудіозаписів та ін. Запис усіх тем у блозі, сайті веде персонально автор Г. Корицька - доцент кафедри філософії та суспільно-гуманітарних дисциплін КЗ «Запорізький обласний інститут післядипломної педагогічної освіти» ЗОР; користувачі можуть записати свої коментарі. Зокрема, у згаданому блозі подано інформацію «V Міжнародний інтернет-форум у Запоріжжі: запрошення до спілкування» 3 виходом через посилання на секцію 2 «Мовнолітературна освіта: сучасний вимір», на сторінці цієї секції за допомогою системи Google створено форму «Запрошення до обговорення!» для спілкування користувачів. У рубриці «Методичний вимір» цього блогу подано методичні рекомендації 3 проведення моніторингу якості загальної середньої освіти; аудіовідеофрагменти на допомогу в проведенні уроку розвитку мовлення (опис процесу праці). У рубриці «Лінгводидактика» розміщено актуальні статті вчених: М. Пентилюк - про розвиток української лінгводидактики в контексті Держстандарту базової і повної освіти в Україні, Г. Корицької - про реалізацію соціокультурної змістової лінії на уроках української мови тощо. Значно ширше фахова інформація представлена на сайті «Камертон філолога: 
відлуння». Меню названого сайту містить низку рубрик професійно-педагогічного спрямування. Зокрема, у рубриці «Лінгводидактика» йдеться про роботу «круглого столу» на тему «Урок української мови в системі компетентнісної освіти», присвяченого пам'яті члена-кореспондента НАПН України, доктора педагогічних наук, професора О. Біляєва (матеріал «Слово про майстра й про сучасний урок української мови»), можна переглянути світлини на згадку про цей захід (веб-фотоальбом), поряд інший матеріал — «Слово про колегу й про лінгвокультурологічний підхід до вивчення української мови». У рубриці «Методика мови» зазначеного сайту, крім матеріалу, що є в згаданій до цього рубриці, уміщено корисну інформацію про авторську педмайстерню учителів української мови Запорізької області (ця майстерня запрацювала на ідеях дистанційного навчання в Запорізькому ОІППО), є посилання на цікаві розвивальні відеоресурси Інтернету «Вчимося рахувати українською», «Учимо український алфавіт: абетка для дітей...», «Складні слова», завдяки чому користувачі у вільному режимі можуть попрацювати 3 посиланнями й відповідними ресурсами. У рубриці «Творча майстерня» наведено короткі тексти в жанрі слова («Слово ...») про творчих учителів-словесників Запорізької області. Отже, сайт «Камертон філолога: відлуння», на відміну від суто інформаційних чи власне навчальних функцій, особливий тим, що виконує інформаційне, освітнє, лінгводидактичне й лінгвометодичне призначення. Створені за допомогою засобів IКТ освітні блоги й сайти, які презентують актуальні теоретико-практичні ідеї навчання української мови, $\epsilon$ сучасними інструментами об'єднання суб'єктів інноваційної професійно-педагогічної діяльності в інформаційному веб-середовищі з метою надання тематичної інформації, навчально-методичних рекомендацій, обміну думок, наукових напрацювань і відкритого спілкування із зацікавленими фахівцями.

Безумовно, важливим напрямом і водночас джерелом розвитку вітчизняної електронної лінгводидактики є здійснення теоретико-експериментальних досліджень актуальних питань упровадження засобів ІКТ в практиці мовної освіти. Це питання використання електронних баз лінгвістичних ресурсів 3 метою навчання, зокрема електронних ресурсів корпусної лінгвістики, питання формування лінгводидактичної компетентності на основі використання засобів IКТ та ін. У контексті сказаного К. Климова в тісній співпраці з Національним центром «Мала академія наук України» вивчає можливості електронної програми TextTermin як аналітичного інструменту для виконання учнями і студентами науково-дослідницької роботи з української мови. На основі результатів проведення контент-аналізу лексики збірки Т. Шевченка «Кобзар» (у навчальному процесі освітнього закладу) дослідниця зазначає, що кількісно-якісна характеристика лексем масиву текстів, виконана за допомогою програми TextTermin, дає змогу користувачам програми встановити кількість слововживань і з'ясувати за допомогою автоматично знайдених контекстів семантичні відтінки, надані Т. Шевченком окремим словам, побудувати між цими словами «дерево відносин» [2, c. 28]. Для навчальної й дослідницької роботи за цією програмою можна використовувати словники, довідники, наукові статті, монографії та інші матеріали, знайдені в мережі Інтернет, відповідно до поставленої мети й завдань. Такі інформаційні інтернет-матеріали допомагають якісно опрацювати зібрані дані, інтерпретувати й оцінити конкретний текстовий матеріал, сприяють пізнавальнопошуковій і творчій активності учнів (студентів).

\section{4. ВИСНОВКИ ТА ПЕРСПЕКТИВИ ПОДАЛЬШИХ ДОСЛІЖЕНЬ}

Отже, розглянуті вище напрями вітчизняної електронної лінгводидактики розкривають сучасні тенденції іiі розвитку, які, у свою чергу, формують закономірності комп'ютерного навчання української мови. Ці тенденції пов'язані з розробленням 
електронних лексикографічних праць навчального призначення, електронних версій підручників i навчальних посібників, навчально-методичних комплексів для комп'ютерних мереж системи освіти, навчально-методичних портфелів в електронному форматі, уроків з використанням IКТ, зі створенням електронних навчальних курсів, блогів i сайтів навчально-методичного спрямування, 3 проведенням наукових досліджень у сфері електронного навчання української мови. Більш детального студіювання потребують перспективні питання активізації навчально-пізнавальної діяльності учнів у шкільному курсі української мови 3 використанням засобів IКТ, створення освітнього порталу для забезпечення україномовної освіти, розроблення й удосконалення програмно-технічних комп'ютерних ресурсів для дистанційного навчання української мови в системі освітніх закладів різних типів.

\section{СПИСОК ВИКОРИСТАНИХ ДЖЕРЕЛ}

1. Intel® Навчання для майбутнього / [Автори оригінального видання Деббі Кендау, Дженніфер Доерті, Джуді Йост, Пейдж Куні; автори адаптації до українського видання Н. В. Морзе, Н. П. Дементієвська]. К. : Нора-прінт, 2005.

2. Климова К. Я. Програма TextTermin як аналітичний інструментарій контент-аналізу лексики збірки Т. Г. Шевченка "Кобзар" студентами та школярами-дослідниками / К. Я. Климова // Лінгводидактичні аспекти фахової підготовки майбутнього вчителя : [зб. наук. праць; за матеріалами VI Всеукраїнського наук.-метод. семінару викладачів і студентів, 27 березня 2014 р.] / за ред. К. Я. Климової. - Житомир : Вид-во ЖДУ ім. І. Франка, 2014. - С. 28-32.

3. Корицька Г. Р. Камертон філолога: відлуння [Електронний ресурс] / Г. Р. Корицька. - Режим доступу : http://korycja-kamerton.hol.es/ від 23.04.2014.

4. Корицька Г. Р. Камертон філолога [Електронний ресурс] / Г. Р. Корицька. - Режим доступу : http://korycja50.blogspot.com/p/blog-page_20.html від 23.04.2014.

5. Мацько Л. І. Мережевий навчально-методичний комплекс вивчення української мови як іноземної [Електронний ресурс] / Л. І. Мацько, Т. М. Кудіна // Інформаційні технології і засоби навчання. 2011. - $\quad$ № 2 (22). http://journal.iitta.gov.ua/index.php/itlt/article/view/415/397\#.U1-zFIF_uTw від 28. 04. 2014.

6. Надолинська А. С. Формування лексикографічної компетенції у студентів філологічних спеціальностей : дис. ... канд. пед. наук : 13.00 .02 «Теорія і методика навчання (українська мова)» / А. С. Надолинська. - Одеса, 2012. - $236 \mathrm{c.}$

7. Омельчук С. А. Українська мова. Готуйся серйоЗНО : електронний практикум [Електронний ресурс] / C. А. Омельчук. - 1 електрон. опт. диск (CD-ROM); 12 см. — Систем. вимоги: Windows 98/ME/NT/2000/XP/Vista/7 Pentium III, HDD 180 Мb відеокарта SVGA звукова карта, CD ROM. Назва $з$ контейнера.

8. Шиліна Г. А. Українська мова. 8 клас. Поглиблене вивчення [Електронний ресурс] / Г. А. Шиліна. - Режим доступу : http://www.zhu.edu.ua/mk_school/course/view.php?id=46 від 28. 04. 2014.

Матеріал надійшов до редакиї 06.05.2014 p.

\section{ОСНОВНЫЕ НАПРАВЛЕНИЯ РАЗВИТИЯ ЭЛЕКТРОННОЙ ЛИНГВОДИДАКТИКИ}

\section{Кучерук Оксана Анатольевна}

доктор педагогических наук, доцент, профессор кафедры дидактической лингвистики и литературоведения

Житомирский государственный университет им. Ивана Франко, г. Житомир, Украина okucheruk1@rambler.ru

Аннотация. В статье рассматривается проблема электронной лингводидактики. Обоснована актуальность создания и использования новых программных средств информационно-коммуникационных технологий с целью повышения качества украиноязычного образования. Путем анализа и синтеза научно-методических идей 
определены основные направления развития отечественной электронной лингводидактики. Эти направления касаются разработки электронных лексикографических трудов учебного назначения, учебников и учебных пособий, электронных версий учебно-методических комплексов, учебно-методических портфелей в электронном формате, уроков с использованием ИКТ, создания электронных учебных курсов, блогов, сайтов учебнометодического направления, проведения научных исследований в области электронного обучения украинскому языку.

Ключевые слова: электронная лингводидактика; электронные средства обучения; электронный учебный курс; информационно-коммуникационные технологии.

\title{
MAIN DIRECTIONS OF ELECTRONIC LINGUODIDACTIC DEVELOPMENT
}

\author{
Oksana A. Kucheruk \\ Doctor of Pedagogical Sciences, $\mathrm{PhD}$, docent, professor, Department of didactic linguistics and study of \\ literature \\ Zhytomyr Ivan Franco State University, Zhytomyr, Ukraine \\ okucheruk1@rambler.ru
}

\begin{abstract}
Article considers the problem of electronic linguistics. In the article it is grounded topicality of creating and using of new software tools of information and communication technologies to improve the quality of Ukrainian-language education. By the analysis and synthesis of scientific and methodological ideas we have defined the main directions of development of the domestic electronic linguistics. These areas relate to the development of electronic lexicographic works for educational purposes, textbooks and teaching aids, electronic versions of the teaching materials, teaching portfolios in electronic format, lessons using ICT, creating e-learning courses, blogs, websites, educational and methodological directions for scientific research in the field of Ukrainian language e-learning.
\end{abstract}

Keywords: electronic linguodidactic; electronic teaching aids; electronic training course; information and communication technologies.

\section{REFERENCES (TRANSLATED AND TRANSLITERATED)}

1. Intel ${ }^{\circledR}$ Education for the Future / [avtory oryghinaljnogho vydannja Debbi Kendau, Dzhennifer Doerti, Dzhudi Jost, Pejdzh Kuni; avtory adaptaciji do ukrajinsjkogho vydannja N. V. Morze, N. P. Dementijevsjka]. — K. : Nora-print, 2005 (in Ukrainian).

2. Klymova K. Ja. Program TextTermin as analytical tools of content analysis of vocabulary collection Shevchenko T. G. «Kobzar» students and students-researchers // Linghvodydaktychni aspekty fakhovoji pidghotovky majbutnjogho vchytelja : [zb. nauk. pracj; za materialamy VI Vseukrajinsjkogho nauk.-metod. seminaru vykladachiv i studentiv, 27 bereznja 2014 r.] / za red. K. Ja. Klymovoji. Zhytomyr : Vyd-vo ZhDU im. I. Franka, 2014. - S. 28-32 (in Ukrainian).

3. Korycjka Gh. R. Tuning Linguistics: echo [online]. — Available from : http://korycjakamerton.hol.es/ (in Ukrainian).

4. Korycjka Gh. R. Tuning Linguistics [nline]. - Available from : http://korycja50.blogspot.com/p/blog-page_20.html (in Ukrainian).

5. Macjko L. I., Kudina T. M. Network of educational and methodical complex study of the Ukrainian language : [online] // Informacijni tekhnologhiji i zasoby navchannja. - 2011. — № 2 (22). Available from : http://journal.iitta.gov.ua/index.php/itlt/article/view/415/397\#.U1-zFIF_uTw (in Ukrainian).

6. Nadolynsjka A. S. Formation of the lexicographic competence in students of philological specialties : dys. ... kand. ped. nauk : 13.00 .02 «Teorija i metodyka navchannja (ukrajinsjka mova)». — Odesa, 2012. - 236 s. (in Ukrainian).

7. Omeljchuk S. A. Ukrainian language. Seriously Get Fit : elektronnyj praktykum [Elektronnyj resurs]. - 1 elektron. opt. dysk (CD-ROM) ; 12 sm. - System. vymoghy : Windows 98/ME/NT/2000/XP/Vista/7 Pentium III, HDD 180 Mb videokarta SVGA zvukova karta, CD ROM. Nazva z kontejnera (in Ukrainian).

8. Shylina Gh. A. Ukrainian language. Grade 8. In-depth study [online]. - Available from : http://www.zhu.edu.ua/mk_school/course/view.php?id=46 (in Ukrainian). 